$\xi=-1$

\title{
Criminal Legal Protection of Property in Russia in the Conditions of Development of Property Relations
}

\author{
Aleksandr Vasilievich Groshev, Aleksandr Georgievich Saprunov, Andrey Vladimirovich Shulga, Romen \\ Rakhimmulovich Galiakbarov, Aleksandr Aleksandrovich Tushev
}

Kuban State Agrarian University, Russia, 350044, Krasnodar, Kalinina Street, 13

\begin{abstract}
The main purpose of the work is to prove that the subject of thefts and other crimes against proprietorship, which is property, should be interpreted in a broad sense - not only as choses, but also as other property, including property rights. The method of achieving this goal is to justify the fact that in the conditions of building an information society and developing market economy, the field of property turnover is expanding. Economic relations increasingly include both material benefits - choses - and other property that does not have any physical parameters of a traditional chose, being incorporeal, intangible, having the information nature. This tendency is undoubtedly taken into account by the criminal environment, which increasingly often commits crimes aimed at unlawful acquisition of this incorporeal property.

Therefore, it is required to strengthen the legal protection of nonmaterial property by criminal legal means, recognizing the thefts of both choses and material goods as the subjects of crimes against property. As a result of unlawful acquisition of these goods, property damage is also caused to their owners. The recognition of property rights as the subject of theft determines the novelty of this article.
\end{abstract}

Keywords: choses, criminal law, economy, property, property rights, proprietorship, the subject of theft.

\section{Introduction}

\subsection{Development of the Economy}

The new epoch of human development is related to the construction and development of the information society. In such a society, the market economy is characterized by the development of industries associated with the turnover (production, distribution and exchange) of information, which thus acquires a particular economic value.

The reason for the participation of information in the economic turnover is the development of modern information technologies based on digital or computer data processing, which are implemented in virtually all fields of human life, including commoditymoney, property relations.

Thus, in the conditions of building an information society, expanding the scope of the use of information technologies and computerized systems, including in market relations, further development of the economy takes place. The economy acquires an innovative nature. Not only material goods, choses (natural resources, real estate, etc.) become the subject of commodity exchange and commercial transactions.

Thus, in the Address to the Federal Assembly of the Russian Federation of 2007, the President of Russia pointed out that competitive economy, based on intellect and knowledge, should be created, i.e., the economy driven mostly not by the pace of development of natural resources, but by the inventions, ideas and the ability to introduce them promptly into real life [1].

The words of the Russian President were confirmed in 8 years. In 2015, in the Address to the Federal Assembly of the Russian Fed- eration, the head of state declared: "Last year we faced serious economic challenges. The prices for oil, our other traditional export goods fell... The difficulties in the economy affect the income and in general the level of life of our people ... But this does not mean that we should calm down and wait for everything to change with a wave of a magic wand, or simply wait for the increase in the price for oil. Such an approach is in principle unacceptable ... The current trends should not be overlooked by the main trends of global development. The outlines of the world economy are changing rapidly; new trade coalitions are being formed, radical changes in the field of technology are taking place. It is precisely now that the positions of countries in the global division of labor are determined for decades ahead, and we can and must take our place among the leaders. Russia has no right to be vulnerable. We need to be strong in the economy, in technology" [2].

Thus, the laws of social development dictate their conditions. Other types of property are also introduced increasingly in modern property relations, in the legal economic turnover, in addition to choses, material goods. These are the goods deprived of property attributes, but generating property rights from their owners or legal owners. These are property goods, values that are informational in nature, i.e. they are incorporeal, intangible, not related to the objects of the material world and, accordingly, not possessing the physical parameters of a traditional chose (such as length, width, weight, volume, etc.).

These intangible (immaterial, incorporeal) values, which are of an informational nature, are increasingly subject to property relations in such fields as financial capital, paperless securities, in high-tech fields (turnover of electronic money in the system of cashless payments, payment for services, mobile communication), including those related to the use of the Internet (Internet money, Internet property, software, Internet sites, etc.), that is, in the field of 
electronic technologies (electronic commerce), in the field of property rights, etc.

\subsection{Criminal Activity}

These new fields of property relations bring significant profits, often exceeding the revenues from transactions with traditional material property (choses). This pattern naturally did not remain without attention from the criminal environment. As a consequence, the situation in the criminal environment in the field of mercenary encroachments has changed. In addition to the accomplishment of crimes against material values, the representatives of the criminal world are increasingly illegally enriched from unlawful possession of the above-mentioned benefits of nonmaterial content.

New forms of criminal activity in the conditions of the modern economy give rise not only to the problems related to their qualification in investigative or judicial practice, but also to the ambiguous assessment by the scientific community.

Thus, modern property relations that are under threat should receive clear legal assessment by the legislator. The criminal law with regard to the protection of property and proprietorship must take into account the above circumstances and establish rules for the qualification of not only crimes against choses as material goods, traditionally considered to be the subject of criminal encroachments against property, thefts, but also encroachments on incorporeal property, including property rights.

As the Constitutional Court of the Russian Federation prescribes, in situations where the mechanisms existing in the criminal legislation do not correspond to the current public realities, which leads to insufficient protection of the values provided for in the Constitution, the legislator must bring the criminal legal norms in line with the current realities of society [3].

It should be noted that the unlawful possession of immaterial property or property rights of another also causes real (actual) material damage and is associated with a reduction in the available property of the victim.

The current criminal law does not take into account this circumstance, does not reflect, therefore, the current realities associated with the development of property relations in the information society with market economy.

Therefore, it is required to increase the level of protection of material property (choses, documentary securities, cash) and other property, including property rights, by the criminal legal means. It is confirmed by the legislative experience of developed world countries, long developing under the market laws.

The level of economic development, the standard of living of the citizens also depends on the quality of all types of property.

The lack of due attention to protection of such an important economic good as intangible property, property rights in the framework of the criminal law; accordingly, the lack of due attention on the part of the law enforcer to combat the encroachments against property rights is the cause of significant increase in crime in this area.

Proceeding from this, there is a need to revise the generally recognized rules for the qualification of the acts related to the unlawful occupancy of the property of another, extending them to the cases of encroachment against nonmaterial, innovative property, including property rights. Given the realities of modern society, it is necessary to change the conceptual approach associated with the content of the concept of "property" as an object of property crimes or crimes against property, including theft; change the views on the content of the property relations themselves, which are the object of property protection in the criminal law.

The development and application of new efficient rules aimed at combating the crimes against the property of another should be regarded as one of the most important areas of policy in the field of protection of rights, as well as the criminal and legal policies that are a means of protecting the current economic development of Russia.

\section{Methods}

The subject of crime is of considerable importance when qualifying, identifying the characteristics of individual convictions, as well as crimes against property. The connection between the subject of crime and the object is direct. The immediate object of encroachment is determined specifically through the subject of crime. The immediate object underlies the definition of the species (group) object, and the species one, in turn, is the generic object of the criminal-legal protection.

The content of public relations, which are the subject of criminal and legal protection, consists of the following elements:

- subjects (participants) of these social relations;

- the subject of public relations, in connection with which (about which) this relationship exists;

- the relationship between these subjects (participants) and the subject.

The subject of public relations in crimes against property acquires the status of the subject of crime, because by influence on this subject public property relations are violated. Public property relations cannot exist without a subject.

Consequently, the content of the object of criminal-legal property protection is largely determined by the content of the crime against property. The subject of crime as such (independently) cannot exist beyond the framework of social relations. However, the object of crime has an independent significance. It predetermines a specific attitude - the object to which the crime is directed. Certain goods that participate in certain social relations act as the subject of crime. Therefore, the study of the subject of crime is of great importance for a thorough and comprehensive investigation of the object of crime [4].

The subject of crime is always associated with specific social relations; it does not exist outside the object of encroachment. The subject of crime does not exist without public relations because only within their framework, only in society a crime can be committed. If one talks about crimes against property, then a chose should be considered a subject of crime against property due to the fact that it is a part of social relations.

Thus, Kudryavtsev, arguing about the interrelation between the object and the subject of crime, has pointed out that the criminal law protects not certain choses or objects as such, but social relations, which are recognized as the objects of crime. On this basis, the definition of the object, its characteristics and the damage to the given object is of great importance for many criminal law institutions [5].

Proceeding from this, the object and the subject of criminal encroachment are interconnected despite their different concepts: the object of crime is social relations, fixed by the rules of law, and the subject of crime (according to the generally recognized concept) is a particular chose (a certain material good). Social relations are born and exist precisely with respect to these benefits. If a chose has no significance, value, then there is no need to establish an order of influence on it. However, this or that good (object, chose, etc.) cannot have signs of a subject of encroachment outside the society, in the absence of subjects, interested in this value. Therefore, the point of view of Nikiforov should be supported, who stated, that the subject of crime was in interconnection with the object, not as the separate parts of a certain unity, dispersed in isolation with respect to each other, but as the elements of a single component - with this particular constituent. Moreover, this whole included not only the subject, but also other elements. So, the subject of crime was an integral part of the object of crime - the public relation [6].

Given this relationship, it should be noted that, taking into account the development of property relations in modern society, it is required to represent more widely not only the subject of property 
crimes, but also to change views on the content of the object of criminal legal property protection - public property relations.

\section{Results}

\subsection{The Concept of Property and Property Rights}

Having analyzed the current version of Chapter 21 of the Criminal Code of the Russian Federation, it should be concluded that property should be understood as the subject of crimes against property. As an exception, fraud and extortion include the subject of crime, such as the right to property. Based on Comment 1 to Art 158 of the Criminal Code, property of another is the subject of theft. But the criminal law does not provide the concept of "property".

The civil law also lacks such a definition. Article 128 of the Civil Code of the Russian Federation "Civil Rights' Objects" only lists the following main objects: choses (which also include documentary securities, cash), as well as other property (including uncertificated securities and noncash money) including property rights. In accordance with this, the meaning of the concept of "property" should be called collective, since it includes not only choses, cash and noncash money, but also documentary or nondocumentary securities, as well as other property that includes property rights.

The basic value in the composition of property objects belongs to choses that are the simplest, most common, understandable and natural type of property. Choses for the most part satisfy the needs of people directly, in the process of owning them [7].

Accordingly, the content of the concept of property in civil law is considered both in the narrow sense - as the aggregate of choses, and in the broad sense - not only choses, but also property rights. The widely used term "property law" also has no legislative definition and is disclosed only in science. In the theory of civil law, the concept of property rights most often includes: the real rights of subjects of civil legal relations that arise as a result of the use, possession and disposal of certain property; mandatory claims that follow from contractual or extracontractual obligations [8,9]; incorporeal rights and civil obligations, or debts [10, 11, 12].

The Decree of the Constitutional Court of the Russian Federation of October 28, 1999 No. 14-P states that property rights should be understood as incorporeal rights and, thus, "the property right is the right of claim of the creditor to the debtor under a civil obligation" [13]. Hence, it can be concluded that a property right arises from the obligation relations, from the relationship between the creditor and the debtor.

If one considers the concept of property used in the framework of Chapter 21 of the Criminal Code of the Russian Federation "Crimes against property", then it can be noted, that the long-term criminal law theory, as well as the judicial and investigative practice, developed their own concept of understanding the attributes of property, which was the subject of these crimes, including the theft.

\subsection{Material Understanding of Property in History}

According to the generally accepted concept, property as a subject of theft has the following attributes: physical, economic and legal. In this, the main one is that the subject of theft has the attributes of a chose, that is, it refers to the material world, is always material [7].

Such a concept is based on the doctrine of F. Engels, according to which the content of property relations "is always connected with choses and manifests as choses" [14]. That is why the property right is called a corporeal right.

Soviet civil law and criminal law science are based on the views of K. Marx and F. Engels on the material nature of property. The socialist doctrine on the criminal-legal protection of material goods by the norms of crimes against property in an unchanged form has also been included into modern criminal law theory and practice.

The ideas pf the material nature of the subject of theft were formed historically. Thus, the representatives of the legal science of prerevolutionary Russia who developed the concept of the three mandatory attributes of the subject of theft defined these signs [ 15 , 16], which were perceived in the process of creating and adopting the Criminal Code of 1903 [17], as well as the Criminal Code of the RSFSR of 1926, and which are currently taken into account. So, Foinitskii wrote that such a subject of embezzlement as property, having a physical nature, must be a corporeal (reified) subject of the material world, to be a chose and to be accessible to man due to sensory perception, tangibility. And it does not matter which senses are affected by any chose, but traditionally this chose is a material chose, an object that can be touched or taken by hand [18].

Speaking about the subject of property crimes as a chose, Zhizhilenko noted its availability to external senses, the possession of a solid, liquid or gaseous state; both animateness and inanimateness, the relevance to the world of plants; the ability of a chose to be a consumed or uncompensated property, perishable or imperishable [19].

Modern scientists, in their majority, are also adherents of the theory that only the corporeal chose about which or in connection with which a criminal act was committed should be recognized the subject of theft as the crime against property [20]. Material objects, choses as the representatives of the material world are the subject of crime [21, 22, 23].

Property as a material chose, which is the result of human work, and consequently possesses value, expressed in price and satisfying human needs, is usually considered a subject of crimes against property. In other words, this or that property (a chose, a commodity or banknotes) has physical (natural) substance. This subject always refers to the material world, material with feelings and has value (or is money as the universal equivalent of value) [24].

\subsection{Material Understanding of Property in Practice}

According to the materialistic concept, such a subject of crime (for example, in the composition of fraud and extortion) as a right to property does not exist independently, in itself. It is always subject to registration by any material carriers (documents, valuable securities, etc.). These material carriers are considered the subject of crimes against property. This conclusion is based on the fact that encroachments on unrealized property values, like uncertificated securities, are not recognized by the criminal law as a crime against property, like embezzlement. This act is considered an encroachment in the field of economic activity and is qualified under Art. 1852 of the Criminal Code - violation of the procedure for recording of the rights to securities.

Thus, defining the concept of the subject of embezzlement, it is noted in a commentary to the criminal legislation of 1996 that such a socioeconomic category as property is associated exclusively with choses, has a material expression in choses. Ownership right is a property right. Therefore, embezzlement should be attributed to substantive crimes, which are often referred to as property crimes. In the objective reality, these encroachments are manifested in the unlawful impact of the guilty on the goods of the material world [25].

Therefore, the generic definition of embezzlement, stipulated by the Commentary 1 to Article 158 of the Criminal Code, which refers to the seizure and (or) circulation of "the property of another", the term "property" means only material substance, a defined object of the material world, a chose possessing such natural and physical parameters as length, width, volume, weight, number, quantity, in other words, real properties.

Thus, in determining the signs of the subject of crimes against property, thefts, the judicial-investigative practice of applying the criminal law took the civilized concept of "property" in the narrow 
sense, i.e. in the sense of choses, applying a restrictive interpretation of this term in Comment 1 to Art. 158 of the Criminal Code.

The same is true of the criminal law theory. For example, in the opinion of Lyapunov, if one considers property in the economic sense, then its material component is a chose. He argues that property, as a social and economic category, is associated exclusively with choses and finds a material embodiment in them. Property is simply unthinkable without its material basis [26].

Such conclusions are the result of a historical solution of this issue. The damage from crimes against property, theft was always associated with a decrease in the volume of property funds (available property) of the victim, with the loss of his belongings (according to the scheme - "put the chose in the pocket and took it away").

According to the Soviet textbooks on the criminal law: "Only what is permitted by the social relations to be disposed, owned and used as property can be stolen actually ... Thus, socialist relations actually limit thefts mainly by personal consumption, household goods, productive livestock, poultry and small farm implements, then there are those about which personal property relations can develop" [27].

The application of socially necessary labor to a chose is traditionally recognized by the economic theory as a criterion for attribution of products, goods of the material world to the category of property. It is labor that gives it the economic attribute of exchange value (and, accordingly, consumer value), as well as the monetary expression of a chose - the price. For example, Pinaev refers to the subject of embezzlement exclusively those items of the material world that have social characteristics. In other words, these are items, in the production of which (extraction from the natural state) human labor is invested, which implements these objects in the stages of production and gives them the property of commodity values $[28,29]$.

\subsection{The Nature of Property and Public Development}

As was noted, the generally accepted relation to the subject of crime as a commodity-material good is based on the Marxist interpretation of property characteristic of the society with traditional economy. According to the classics of Marxism, property is viewed through its relation to the conditions of production as proprietory ones, while property manifests itself through production and appropriation of production, and property relations in their actual form are production relations [30, 31, 32]. This historical period is characterized by the fact that production relations were manifested primarily through the production of property as choses. And this has its own regularity, since the society with traditional economy reproduces property relations, expressed in the turnover of material values, the interconnected functioning of producers and means of production, and the moderate development of commodity exchange. It is in the use of a chose that its consumer value is manifested. In this respect, in traditional society property relations are formed in the majority in the field of possession or use of choses [33].

The authors agree completely with the statement of Bezverkhov: "The subject of property crimes in the conditions of the traditional economy is characterized exclusively by physical, natural-material attributes. They can only be a chose as an object of consumption or a means of obtaining consumed goods. The weak development of the productive forces of society with the traditional economy makes it highly dependent on nature. According to Soloviev, such a society has a natural lifestyle [34]. Consequently, in the society with the traditional economy, production processes, determined and associated to natural processes, predominate [35]. As is known, nature does not know property rights; it does not know property benefits and interests. Hence it becomes clear why under the traditional economy only values of material nature created by human labor are the subject of property encroachment" [33, p. 71]. The traditional economy is based on natural production forces. The main branch of the traditional economy is agriculture [36]. In
Russia, this economic structure has existed historically. Later, in the period of the USSR's planned economy, the concept and content of the subject of crimes against property did not change practically. The object of property crimes were property relations, most of them in the field of property belonging to choses, legally regulated through property rights. That is, in a society with planned economy, the object of the encroachments considered was the economic relations that manifested themselves in the possession, use and disposal of material values. Therefore, under the influence of planned economy, the crimes against property are called "crimes against proprietorship" and are also referred to in the same way in science. Crimes against property rights consist in the unlawful acquisition of the material fruits of the work of another, as well as causing harm to the "material composition" of the property of another [33].

Thus, the characteristic attributes, distinguishing the traditional, planned economy, were the reason for the criminalization of only crimes against material goods, choses created by human labor and therefore having value, price. This was also due to the fact that the state monopoly in the economic field practically nullified the contractual relations between the citizens, excluded the evolution of property relations.

However, if the fundamentals of the functioning of the economy, the development of the market for innovative goods, the development of information and communication technologies change, it is also necessary to take into account the development of property relations.

As was indicated above, after the adoption of the Criminal Code of the Russian Federation in 1996, the definition of the subject of encroachments against property practically did not change. According to the current law, designed to protect property relations developing under the market laws, the subject of crimes against property is also choses of another (as in the criminal law under planned economy). However, the market and planned economies are subject to fundamentally different economic laws, which undoubtedly affects the field of property relations. Therefore, in the authors' opinion, an exclusively real (material) understanding of the subject of crimes against property (proprietorship) does not meet the current realities of the development of market relations in the information society.

\section{Discussion}

\subsection{Information Nature of Property}

In modern conditions, with the development of trade turnover, expansion of property relations, inclusion of property rights (incorporeal rights) in the property mass, socio-economic categories become not only choses but also property rights (incorporeal rights). Material damage may be caused to the victim in the unlawful possession of the latter also.

As was noted by the scientists, the meaning of the object of ownership in the economics has a fairly broad interpretation, which includes not only objects of nature or substance, but also information, energy, intellectual values, individual rights and other objects that have attributions of a good, a market value in terms of economic turnover [33]. In this regard, the positions of modern scientists increasingly go beyond material (objective) or materialistic concepts, both in formulating the attributes of the subject of crime as a whole, and in determining the signs of crimes such as crimes against property, including theft.

The reason for this is the creation and development of the information society, the introduction of information technologies in almost all fields of human relations and, as a consequence, the expansion of the field of modern production and property relations, the introduction of goods as material goods into the commodity circulation.

For example, Klepitskii also holds the view that property interests and rights should also be included in the number of objects of 
property crimes (crimes against proprietorship). According to his position, it is necessary to revive such a legal institution as the institution of property crimes and, consequently, to engage in comprehensive protection of property rights and interests [37], since property rights and interests exist not only in the realm of choses (corporeal goods), but also in the field of incorporeal property (obligations rights, claims rights, etc.) [38].

According to the fair conclusion of Kruglikov, the subject of theft cannot be limited solely to objects of the material world with real attributes; it is necessary to exclude such an outdated concept and also to recognize the right to property as an object of embezzlement [39].

In modern science, the issue that under the conditions of the present society the objects of property rights do not necessarily belong to the material world is discussed quite often. In property relations, both in legal and economic terms, other property benefits are included. The realities of objective reality dictate such conditions that the subject of crimes against proprietorship cannot possess exclusively material attributes. This question is especially relevant in the case of illegal acquisition of another's property using information and telecommunication technologies. This perspective should be taken into account when determining the attributes of theft in the market of innovative products and construction of an information society.

Property can have not only material, but also information nature. Property can possess both material and information value. Therefore, the subject of crimes against proprietorship, theft can also possess this attribute.

\subsection{Property as Property Rights}

Object of crimes against proprietorship should be considered not legal property rights (rights of possession, use and disposal), but economic property relations (the ability of a person to actually exercise the power to own, use and dispose).

Property relations in the economic sense have very wide definition, which arises not only about the objects of nature, matter, material goods, but also energy, information, nonmaterial results of works and services, individual rights, intellectual and other values that, under conditions of economic turnover, possess the attributes of a good.

The forensic scientist Bezverkhov is right, arguing that "the definition of the crime subject can no longer be attributed solely to its real content. For example, the subject of economic crimes can be any economic benefit that is both material and intangible. The main chose is that this good has real or potential economic value, or it was recognized as a possible object of economic turnover, i.e. it took on a commodity form and received a value expression" [33, p. 134].

Also, Novoselov defines the subject of encroachment as a combination of "various kinds of material or intangible goods (values), capable of satisfying the needs of people, the criminal influence on which (or illegal treatment) causes or creates a threat of harm" [40].

As it was noted in the previous sections, scientists in their opinions increasingly go beyond such a "materialistic" understanding not only by defining the subject matter of the crime as a whole, but also by defining specifically the subject of criminal encroachments against proprietorship.

In modern criminal law literature, in particular, the necessity of departing from conventional purely materialistic understanding of the nature of the subject of crime and the subject of theft are considered increasingly often $[41,42,43,44]$. The reason for this is the development of social relations, including the property relations.

The modern reality shows that relations concerning property go beyond the border of material relations and are transformed into broader fields associated with intangible, incorporeal property, property rights. Nonmaterial, immaterial or incorporeal property, including property rights, is also subject to the powers of possession, use and disposal.

Therefore, it can be concluded that such an object of criminallegal protection as property relations should include protection of not only the choses of another, but also of other unrealized property, including property rights (obligation rights, incorporeal rights). Moreover, this rule should be applied in the qualification of theft. It does not correspond to the modern development of commodityproperty relations developing according to the laws of the information society, to connect the object of crime solely with the choses.

Currently, the precondition for this is the change in the socioeconomic formation; financial and economic changes; the development of information technologies in the context of building an information society; the emergence of property relations beyond the generally recognized property relations and the transition to other fields (financial capital, cash in noncash form, uncertificated securities), in the area associated with the functioning of the Internet, high-tech fields (in the field of turnover of Internet property, Internet money, Internet sites, software, etc.), electronic technologies (electronic commerce), the field of property rights, as well as other fields that are fundamentally of an information nature. The market of innovative goods is developing more and more actively.

\subsection{Economic Value of Information}

The scientific and technological progress, which began in the second half of the 20th century, as well as the development of information and communication technologies, actively implemented in various fields of human life, have led to the fact that the concept of "information" has a fundamentally different meaning. From the generally accepted understanding of information as separate information transmitted in written, oral or other ways (by technical means, conditional signals, etc.), information has transformed into substance with market value. Such changes have occurred due to revolutionary inventions in the field of computer technology. As a result of such inventions, new fields of relations in the society began to form - information relations. At the end of the last millennium, information, regardless of the form of its consolidation, has become one of the most important values in society, one of the most expensive products in the market. Previously, the indicator of the development of mankind was the availability of energy to it, while currently the availability of information is such a major factor [45].

As a result of such changes, the growing economic interest from criminals in the information possessing real economic value - in the information that attaches the rights to acquire property, receive services or perform works - in the information of a property nature, can be ascertained. By its legal nature, the information on property (of property nature) is a property right - certain information about the ownership of the rights of a person on the receipt (claim) of property in certain quality and quantity (amount).

One of the main prerequisites of criminal encroachments on objects, goods, the main component of which is information (data), will be its growing value. Free access to the use and dissemination of information, the ease of its reproduction and copying, the increasing pace of scientific and technological progress in the world, especially in the development of various types of information and information technologies [46], stipulate an increase in criminal attacks on such information.

Such negative aspects, as noted above, are related to construction and development of the information society in Russia.

The information society is associated with the ability of information to integrate into production, distribution and exchange processes, as well as any other property. These factors equalize the information of a property nature (property rights), which has real value in market conditions, with material (corporeal) property, which is universally recognized as the subject of crimes against property. 
In other words, information in various forms of its manifestation has real value, can be recognized as property and, accordingly, unlawful, uncompensated withdrawal of it can cause property damage to the rightful owner (victim).

The leading role of information in the economic development is already recognized in Russia, as well as the leading role of information and telecommunications products (technologies) as a special commodity or property. Such facts point to an increase in the public danger of crimes against information as a form of property, the expediency of recognizing it as the subject of crimes in the field of economy, in the field of property encroachment.

\subsection{Property in the Innovative Economy.}

The development of the information society is inextricably linked with the process of the emergence and development of innovative economy in such a society. The information society has a direct connection with the innovation economy, depends on the innovative economy.

The innovative economy is the next stage of development after the agrarian and industrial economy, that is, the innovative economy is the post-industrial economy that is the result of the worldwide socio-economic revolution. This type of economic development lies in the fact that the basis of the production process is the knowledge and results of creativity, focused on innovation (knowledge-intensive innovations). Not production in the material field lies at the heart of competition, but production in the field of technology - ideas, strategies, projects, standards, etc.

In the innovation economy, knowledge, which is in fact information, data, is the main economic value, the commodity. Technology is involved in the production, distribution and consumption processes. A large share of innovation is made up of technologies - the ways of obtaining cardinally new products, new technological knowledge and processes, as well as new methods and principles of production organization.

Innovative processes can also include new ways of organizing property relations, when production, distribution and exchange processes are built on information, including the processes of ownership, use and disposition of property are carried out on the basis of an exchange of information on these processes. At present, most property relations are built in such a way that one does not need to own property in kind (as a chose), "keep it in hands" (as the civil law traditionally discloses the power of ownership). It is enough to have the information that this property belongs to someone. Similarly, to receive the benefit from the property (to use it), to dispose of it (to transfer to other persons) is possible at the level of information exchange. And this cannot be ignored by the criminal law aimed at protecting property relations, including the articles on crimes against property, embezzlement [47].

The innovative economy (from English "innovation" - novelty, novation, pioneer work) generates new types of goods, competitive products, technologies, that is, new fields of property relations that go beyond the traditional real commodity turnover, the traditional material field. There is development of innovative entrepreneurship, innovative economic activity, including new types of property. New economic benefits in innovative economy also have value; the encroachments on them cause real property damage, which requires the protection of these goods, as well as traditional property, under criminal law.

Property relations also move into automated and computerized fields. There are new nonmaterial goods that have value, price and are involved in the processes of production, distribution and exchange. These benefits are also extended to the triad of eligibility - possession, use and disposal. Various information resources acquire the economic form of the goods.

E-commerce is developing; the electronic means of payment are used in everyday life, along with cash and noncash money.

The production, reception, processing, transfer, and exchange of the information testifies to the participation of information, like any other economic good, in property relations, the development of property relations in the information field.

Innovation is the most valuable modern economic commodity, the property of informational nature that should receive proper criminal and legal protection in accordance with the field of social relations - economic social relations. The public danger of infringement of these goods in the conditions of modern society is undoubtedly increased.

Building innovative economy is one of the priority, strategic directions of Russia's development at present. The strategy of the national security of the Russian Federation until 2020 directly points to the importance of innovative economy in the development of Russia, the emergence of new innovative products in the market, the risk of encroachment on its main innovative values (benefits, results of innovation) and, thus, the need to strengthen them including the criminal law means.

In the Strategy for the Innovative Development of the Russian Federation for the Period to 2020, it is correctly stated that the transition of the Russian economy to an innovative sociallyoriented model of development is the only possible way to achieve the goal of ensuring a high standard of living for people and affirming the role of our state in the world of the leading power that will determine the vector of world development.

The emergence and development of new property relations in the field of innovation, new types of innovative products, innovative property is also noted herein.

\subsection{Historical Nature of Proprietorship}

Thus, in the conditions of the innovative economy, not only material goods, choses, but also new types of commodity, the property devoid of material (real) attributes and having the information nature, take part in the property turnover.

Thus, in the conditions of building an information society and innovative economy, information in various forms of its expression becomes particularly important, is included in property relations, has value, and infringements on it cause real property damage. Nonmaterial attributes of property should be used as a basis for a new conceptual methodology in determining the characteristics of the crime subject in criminal law, as well as the subject of crimes against proprietorship, theft.

Everyone knows that property developed historically. In the process of the development of society, its content is subject to change. So, there was a transition from primitive communal proprietorship to slave proprietorship, then - to feudal proprietorship, and then to capitalistic proprietorship. For example, in the process of adoption of the Criminal Code of 1903 (which also ensured the protection of property relations in the market conditions of prerevolutionary Russia), it was noted by the editorial committee that the protection of the property interests of citizens should not be limited to countering crimes that, as an object, provide for property in the sense of material (physical) choses. Property "may be the object of encroachment, not only in the face of specific physical choses, but also in the person of the totality of choses embraced by some right or obligation for property that have not yet been embodied in concrete choses" (Criminal Code, 1904). Thus, property as a crime subject of that period was considered in a broad sense as a set of property rights, values belonging to a person and having an exchange value [37].

The world-famous philosopher G.V.F. Hegel has correctly pointed out that the spiritual abilities, arts, sciences, inventions can be the subject matter of a contract and are equated to choses by the way of sale or purchase: "... is an artist, scientist, etc. in the legal possession of his art, his science, his ability to read a sermon, mass, that is, do such things that represent choses? ... Knowledge, science, talents, etc. ... are characteristic of free spirit and represent its internal qualities, and not something external; but he can also, through reification, impart to them an external existence and alienate them ..., as a result of which they are brought under the definition of choses" [48]. 
Currently, property protection should meet the needs of building an information society with market innovation economy. Such changes are objectively related to the development of the productive forces of society, information and communication technologies.

\subsection{Information as Property, Goods}

Since at present property relations are broader than those to which people are accustomed, it is much more effective to have ways to protect the property represented as intangible goods - the information within the object of criminal and legal property protection. Paying attention to the nonmaterial attributes of the subject of property crimes, it should be noted that at the present time, in the conditions of the development of information systems, computer technologies, not only choses as physical objects with physical parameters have price as a monetary expression of the exchange value. Currently, various types of property are bought and sold, including the property, represented in the form of information of an informational nature - intellectual property (results of intellectual activity), patent and inventor's rights, copyright and related rights; various data, concentrated in computers and other high-tech devices, software, etc.

A product such as information increasingly becomes the subject of trade, market relations. Information sometimes is very expensive. In the conditions of innovative economy, market competition, any unlawful acquisition of such information causes significant damage in the activities of enterprises, institutions or organizations. The unlawful acquisition of information under current conditions has a high level of public danger, which requires an increase in the criminal law struggle against such acts, including in the framework of crimes against property in the Criminal Code.

It has been stipulated in the current legislation for a long time that the information acts as a special object of contractual relations, i.e. it acquired the purpose of the goods. It is stipulated in Part 3, Art 6 of the Law "On Information, Information Technologies and Information Protection" that the person to whom the information belongs has the right to use it, and also to transfer it to others under the contract.

For example, Article 1 of the Federal Law No. 98-FZ of July 29, 2004 (as amended on March 12, 2014) "On Commercial Secrets" states that this Federal Law regulates the relations associated with the establishment, modification and termination of the commercial secret regime in respect of the information that has a real or commercial value due to its nonpublic nature.

This rule indicates that any commercial secrets are information and, as it has value, they can be a commodity and subject of civil contracts.

Thus, with the development of new economic and property relations, not only public relations in the field of protecting other material property, but also social relations, in the field of protecting property benefits, deprived of material (real) nature, that is, nonmaterial property, including property rights, should be recognized as the objects of crimes against proprietorship, thefts.

Therefore, Comment 1 to Article 158 of the Criminal Code of the Russian Federation, where the notion of embezzlement is formulated, proposes to interpret the words "... property of another ...", defining the subject of thefts, not restrictively only as material (corporeal) goods, but broadly as material (corporeal), and immaterial property benefits, the possession of which causes material damage to their owners or other proprietors. Such a proposal will have an applied value, allowing more effective application of the criminal law in protection of not only material property, but also of the immaterial one.

\section{Conclusion}

Thus, the subject of crimes against property should be understood as material (corporeal) or immaterial goods (other property, in- cluding property rights) of another, that are included in the official economic turnover and therefore having valid (as a result of human labor) or market value, illegal seizure and (or) acquisition of which cause material damage to their owners or proprietors.

Such a notion of the subject of crimes against proprietorship, including theft, shows the necessity to interpret the words "... property of another ..." in Comment 1 to Article 158 of the Criminal Code not only as corporeal (material) but also nonmaterial benefits, including property rights, unlawful possession of which causes material damage to their owners.

As noted above, the subject of theft is traditionally understood as the property possessing the following mandatory attributes (properties): physical, economic and legal.

However, as practice shows, in conditions of development of the information technology and the innovative goods market, not physical (material) component, but the ability to be a commodity, that is, the economic attribute should be the most important attribute of property as a subject of theft.

Unfortunately, after the adoption of the Criminal Code in 1996, the interpretation of the subject of crimes against proprietorship has not changed. According to the current criminal law, the choses of another remain to be the subject of the above crimes in the market economy - as well as the subject of crimes against proprietorship, theft in the planned economy. However, the market and planned economy are subject to fundamentally different economic laws, which undoubtedly affects the field of property relations. Therefore, in the authors' opinion, an exclusively real (material) understanding of property as an object of crimes against property, theft does not reflect the current state of development of market property relations in the conditions of building an information society.

According to modern economic theory and practice, property manifests itself not only in the objects of the material world, choses. Both materialized (corporeal) and nonmaterialized (incorporeal), material and immaterial values take part in property relations of proprietorship. Actual property relations increasingly involve incorporeal values, the value of which is not conditioned by human labor, but which also have price as a monetary expression of the economic value. Therefore, in the conditions of market relations, taking into account the requirements of law enforcement practice, it is proposed to consider such nonmaterialized goods as the information of property nature, property rights, etc., as a subject of crimes against proprietorship.

The words of Foinitskii should be taken into account, who has pointed out that real life dictates a direct link between the economic development and the expansion of the scope of punishable property protection [16, p. 372]. One must agree that the change in the economic structure of society, the transition from one type of economy to another, underlies the changes in the field of economic crime, the crimes against property. Criminal behavior taking place in one economic order may not pose a threat to another type of economy (for example, speculation) and vice versa. According to Karpets [49], "every economic system generates its own crime". The existence of market relations in the Russian Federation, the development of property turnover, the involvement in the trade of qualitatively new types of property, information, property rights, and thus the expansion of the field of property relations, necessitate their adequate criminal and legal protection. These factors, of course, should be taken into account when determining the subject and object of the criminal acts in question.

The recognition of property rights as a subject of economic, property crimes, that is, crimes against proprietorship, theft, raises the issue of recognizing property rights of intellectual property owners (the results of intellectual activity) as the subject of economic crimes. Further research of this issue is required.

In conclusion, the authors express their appreciation to all the scientists, who dealt with the problems of criminal and legal protection of property, the works of which were referred to when writing this article. 


\section{References}

[1] Poslanie Prezidenta Rossiiskoi Federatsii Federalnomu Sobraniyu RF [Address of the President of the Russian Federation to the Federal Assembly of the Russian Federation], April 27, 2007.

[2] Poslanie Prezidenta Rossiiskoi Federatsii Federalnomu Sobraniyu RF [Address of the President of the Russian Federation to the Federal Assembly of the Russian Federation], December 3, 2015.

[3] "Po delu o proverke konstitutsionnosti polozhenii stati 159.4 Ugolovnogo kodeksa Rossiiskoi Federatsii v svyazi s zaprosom Salekhardskogo gorodskogo suda Yamalo-Nenetskogo avtonomnogo okruga". Postanovlenie Konstitutsionnogo Suda RF ot 11.12.2014 N 32-P ["On the Case on the Verification of the Constitutionality of the Provisions of Article 159.4 of the Criminal Code of the Russian Federation in Connection with the Request of the Salekhard City Court of the Yamalo-Nenets Autonomous District". Decree of the Constitutional Court of the Russian Federation No. 32-P]. http://www.pravo.gov.ru. Revised December 11, 2014. Accessed June 29, 2018.

[4] A.V. Shulga, Obekt i predmet prestuplenii protiv sobstvennosti v usloviyakh rynochnykh otnoshenii i informatsionnogo obshchestva [The Object and Subject of Crimes against Property in the Context of Market Relations and the Information Society], Moscow, 2007, p. 147 .

[5] V.N. Kudryavtsev, O sootnoshenii predmeta i obekta prestupleniya po sovetskomu ugolovnomu pravu [On the Relationship between the Subject and the Object of the Crime on Soviet Criminal Law], Trudy Voenno-yuridicheskoi akademii [Proceedings of the Military-Law Academy], Issue 13, 1951, p. 66-67.

[6] B.S. Nikiforov, Obekt prestupleniya po sovetskomu ugolovnomu pravu [The Object of Crime of Soviet Criminal Law], Moscow, 1960, p. 122-133.

[7] G.N. Borzenkova, V.S. Kommissarov (eds.), Kurs ugolovnogo prava. Osobennaya chast. Tom 3. Uchebnik dlya vuzov [The Course of Criminal Law. Special Part. Vol. 3. Textbook for Higher Schools], IKD ZertsaloM, Moscow, 2011, p. 230.

[8] R. David, Osnovnye pravovye sistemy sovremennosti [Basic Legal Systems of Our Time], Moscow, 1988, p. 90-92.

[9] L. Lapach, Ponyatie "imushchestvo" v rossiiskom prave i v Konventsii o zashchite prav cheloveka i osnovnykh svobod [The Concept of "Property" in Russian Law and in the Convention for the Protection of Human Rights and Fundamental Freedoms], Rossiyskaya yustitsiya 1 (2003).

[10] N.V. Apolinskaya, Opredelenie veshchi kak obekta grazhdanskogo prava Rossiiskoi Federatsii [Definition of a Chose as an Object of Civil Law of the Russian Federation], Sibirskii yuridicheskii vestnik 1(25) (2002)

[11] N.N. Averchenko, Sootnoshenie termina "veshch" i smezhnykh ponyatii v grazhdanskom prave [Correlation of the Term "Chose" and Related Concepts in Civil Law], Yurist 11 (2003) 2-6.

[12] N.N. Averchenko, Ponyatie i priznaki veshchi kak obekta grazhdanskikh prav [The Concept and Attributes of a Chose as an Object of Civil Rights], Zhurnal rossiyskogo prava 5 (2004) 86-92.

[13] V.P. Kamyshanskii, N.M. Korshunova, V.I. Ivanova (eds.), Grazhdanskoe pravo: uchebnik v trekh chastyakh. Chast pervaya [Civil Law: A Textbook in Three Parts. Part One], Eksmo, Moscow, 2010 , p. 258.

[14] K. Marx, F. Engels, Sochineniya [Works], Volume 13, Moscow, 1959 , p. 498

[15] V.V. Esipov, Ugolovnoe pravo: Chast osobennaya. Prestupleniya protiv lichnosti i imushchestva [Criminal Law: Special Part. Crimes against the Person and Property], St. Petersburg, 1899, p. 139.

[16] I.Ya. Foinitskii, Kurs ugolovnogo prava: Osobennaya chast. Posyagatelstva lichnye i imushchestvennye [The Course of Criminal Law: Special Part. Personal and Property Encroachments], St. Petersburg, 1912, p. 169-173.

[17] Ugolovnoe Ulozhenie 22 marta 1903 g. S motivami, izvlechennym iz obyasnitelnoi zapiski redaktsionnoi komissii, predstavleniya Min. Yustitsii v Gos. Sovet i zhurnalov - osobogo soveshchaniya, osobogo prisutstviya departamentov i obshchego sobraniya Gos. Soveta [Criminal Code of 22 March 1903 (with motives extracted from the Explanatory Comment of the Drafting Committee, the Submission of the Ministry of Justice in the State Council and the journals of the Special Council, the Special Court of Departments and the General Meeting of the State Council], Publishing House of N.S. Tagantsev, St. Petersburg, 1903, pp. 832-833.

[18] I.Ya. Foinitskii, Kurs ugolovnogo prava. Chast osobennaya. Posyagatelstva lichnye i imushchestvennye [The Course of Criminal
Law. Special Part. Personal and Property Encroachments], St. Petersburg, 1901, p. 162.

[19] A.A. Zhizhilenko, Prestupleniya protiv imushchestva i isklyuchitelnykh prav [Crimes against Property and Exclusive Rights], Leningrad, 1928 , p. $6,13,14$.

[20] L.D. Gaukhman, S.V. Maksimov, Otvetstvennost za prestupleniya protiv sobstvennosti [Responsibility for Crimes against Property], Moscow, 1997, p. 65.

[21] L.D. Gaukhman, Kvalifikatsiya prestuplenii: zakon, teoriya, praktika [Qualification of Crimes: Law, Theory, Practice], Moscow, 2001, p. 84-85.

[22] Yu.L. Shevtsov, K voprosu ob obekte vymogatelstva [On the Subject of Extortion], Pravo i demokratiya [Right and Democracy], Issue, St. Petersburg, Minsk, 1997, p. 25.

[23] V.V. Khilyuta, Prestupleniya protiv sobstvennosti i poryadka osushchestvleniya ekonomicheskoi deyatelnosti: kontseptualnye osnovy modeli-rovaniya obekta i sistemy [Crimes against Property and the Order of Economic Activity: The Conceptual Basis for Modeling an Object and System], Moscow, 2012, p. 67.

[24] Yu.I. Lyapunov, Otvetstvennost za vymogatelstvo [Responsibility for Extortion], Zakonnost 4(5) (1997).

[25] Yu.I. Skuratov, V.M. Lebedev (eds.), Kommentarii k Ugolovnomu kodeksu Rossiiskoi Federatsii. Osobennaya chast [Commentary on the Criminal Code of the Russian Federation. Special Part], Moscow, 1996, p. 110.

[26] N.I. Vetrov, Yu.I. Lyapunov, Ugolovnoe pravo: Osobennaya chast [Criminal Law: Special Part: Textbook], Novyi yurist, Moscow, 1998 , p. 203

[27] N.A. Belyaev, M.D. Shargorodskii (eds.), Kurs sovetskogo ugolovnogo prava: v 5-ti t. T. 3. Chast osobennaya [The Course of Soviet Criminal Law: In 5 Volumes. Vol. 3. Special Part] (pp. 355-356), Leningrad University Publishing House, Leningrad, 1973.

[28] A.A. Pinaev, Ugolovno-pravovaya borba s khishcheniyami [Criminal and Legal Struggle Against Theft], Kharkov, 1975, p. 49.

[29] A.A. Pinaev, Problemy dalneishego sovershenstvovaniya sovetskogo ugolovnogo zakonodatelstva ob otvetstvennosti za khishcheniya. Avtoref. dis. ...dokt. yurid. nauk [Problems of Further Improvement of the Soviet Criminal Law on Liability for Theft (Ph.D. Thesis Abstract)], Kiev, 1984, p. 12-13.

[30] K. Marx, F. Engels, Sochineniya [Works], Volume 4, Moscow, 1955 , p. 168.

[31] K. Marx, F. Engels, Sochineniya [Works], Volume 16, Moscow, 1960, p. 26.

[32] K. Marx, F. Engels, Sochineniya [Works], Volume 27, Moscow, 1962, p. 406.

[33] A.G. Bezverkhov, Imushchestvennye prestupleniya [Property Crimes], Samara, 2002, p. 70.

[34] S. Soloviev, Istoriya Rossii s drevneishikh vremen [History of Russia from Ancient Times], Volume 1, Moscow, 1857, p. 1.

[35] R.M. Nureev, Politicheskaya ekonomiya. Dokapitalisticheskie sposoby proizvodstva. Osnovnye zakonomernosti razvitiya: Uchebno-metodicheskoe posobie dlya studentov ekon. fak. gos. untov [Political Economy. Preacpitalist Methods of Production. Basic Regularities of Development: Text Book for the Economy Department Students of Universities], Publishing House of Moscow State University, Moscow, 1991, p. 8-9.

[36] I.S. Berezin, Kratkaya istoriya ekonomicheskogo razvitiya: Uchebnoe posobie [Short History of Economic Development: Textbook], Russkaya delovaya literature, Moscow, 1998, p. 16.

[37] I.A. Klepitskii, Sobstvennost i imushchestvo v ugolovnom prave [Property and Proprietorship in Criminal Law], Gosudarstvo i pravo 5 (1997) 74-83.

[38] I.A. Klepitskii, Obekt i sistema imushchestvennykh prestuplenii v svyazi s reformoi ugolovnogo zakonodatelstva Rossii: avtoref. dis. ... kand. yurid. nauk [The Object and System of Property Crimes in Connection with the Reform of the Criminal Legislation of Russia (Ph.D. Thesis Abstract)], Moscow, 1995, p. 12.

[39] L.L. Kruglikov, Problemy teorii ugolovnogo prava: izbrannye stati, 2000-2009 gg. [Problems of the Theory of Criminal Law: Selected Articles, 2000-2009], Yaroslavl, 2010, p. 541, 546.

[40] G.P. Novoselov, Uchenie ob obekte prestupleniya. Metodologicheskie aspekty [The Doctrine of the Object of Crime. Methodological Aspects], Moscow, 2001, p. 53.

[41] M.P. Bikmurzin, Predmet prestupleniya: teoretiko-pravovoi analiz. Avtoref. diss. ...kandyurid. nauk [Subject of Crime: Theoretical and Legal Analysis (Ph.D. Thesis Abstract)], Saratov, 2005. 
[42] M.M. Vetoshkina, Tsennye bumagi kak predmet khishchenii/Avtoref. diss. ... kand. yurid. nauk [Securities as an Object of Embezzlement (Ph.D. Thesis Abstract)], Ekaterinburg, 2001.

[43] A.P. Sevryukov, Khishchenie imushchestva: kriminologicheskie i ugolovno-pravovye aspekty [Property Theft: Criminological and Criminal Law Aspects], Moscow, 2004.

[44] S.S. Medvedev, Moshennichestvo v sfere vysokikh tekhnologii: Diss. .. kand. yurid. nauk [Fraud in the Field of High Technology (Ph.D. Thesis)], Krasnodar, 2008.

[45] D.A. Kalmykov, Informatsionnaya bezopasnost: ponyatie, mesto y sisteme ugolovnogo zakonodatelstva RF, problemy pravovoi okhrany. Avtoref. diss. ... kand. yurid. nauk [Information Security: Concept, Place in the System of Criminal Legislation of the Russian Federation, Problems of Legal Protection (Ph.D. Thesis Abstract)], Kazan, 2005, p. 3 .

[46] S.A. Yashkov, Informatsiya kak predmet prestupleniya: Avtoref. diss. ... kand. yurid. nauk [Information as the Subject of Crime (Ph.D. Thesis Abstract)], Ekaterinburg, 2005, p. 4.

[47] A.V. Shulga, Khishcheniya v usloviyakh razvitiya sovremennykh informatsionnykh tekhnologii i rynka innovatsionnykh tovarov [Theft in the Conditions of Development of Modern Information Technologies and the Market of Innovative Goods], Moscow, 2016, p. 148 .

[48] G.V.F. Hegel, Filosofiya prava [Philosophy of Law], Moscow, 1990 , p. 102

[49] I.I. Karpets, Ekonomika i prestupnost [Economics and Crime], Zakonnost 3 (1992) 50. 